RESEARCH NOTE

\title{
Human Rights and Development - An International Political Economy Perspective
}

\author{
Cristiane Lucena \\ Institute of International Relations, University of São Paulo (IRI/USP), Brazil
}

\begin{abstract}
This research note provides a critical review of the recent literature on the consequences of development and democratization for the protection of human rights. It identifies common lessons and grounds for further research in the field. This literature takes a series of paradoxes that challenge conventional wisdom regarding the relationship between development and democratization as its starting point, on one hand, and the protection of human rights, on the other. To that effect, several unintended adverse consequences of economic development and movements toward democracy for the protection of civil and political rights are identified. The literature focuses on rights to physical integrity, leaving important questions unanswered when it comes to civil liberties and second-generation rights. The article systematizes new knowledge produced by this literature, translates it into recommendations for research and identifies opportunities for new investigations.
\end{abstract}

Keywords: Human rights; development; democratization.

\section{Introduction}

$\mathrm{O}$ ver the last two decades, the field of human rights has attracted the attention of scholars in Political Science and International Relations working within an international political economy framework. These scholars bring to this research agenda well-established knowledge on democracy and development, drawing from a prolific scholarship. When researchers set out to explore the relationship between human rights and development - and, for that matter, human rights and democracy - they do call on this scholarship to frame their efforts and to guide their exercise.

The systematic evaluation of the level of human rights protection around the world was well under way when the effort to study the relationship between human rights and 
development started, which meant that there was data to carry out large-N studies. Organizations such as Freedom House and databases such as the Political Terror Scale were already committed to providing a systematic overview of the state of human rights protection in the world on a regular basis. The availability of this data prompted a research agenda that relied on quantitative methods and formal modeling. Inevitably, findings and research design choices from the literature on development and democracy influenced this new endeavor.

It is not surprising that we find an important segment of the literature that looks at human rights and development to be predominantly quantitative. I will come back to this aspect of the research agenda later, to point to specific shortcomings in this literature that could perhaps be best addressed through the use of in-depth case study analysis. The article proceeds as follows: Section 2 discusses the research that analyzes democracy and democratization as they relate to the protection of human rights. Section 3 focuses on the relationship between economic development and the protection of human rights, and analyzes the role of several economic tools in the promotion of better human rights practices by states. Section 4 identifies areas for further research and opportunities to deepen our knowledge through the study of specific aspects of a problem, via case study. The last section is the conclusion.

\section{Democracy and Democratization}

International political economy approaches to the relationship between democracy and democratization, on one hand, and the protection of human rights, on the other, have faced several issues of measurement. Measures of democracy vary, but the several measures available have in common the fact that they treat data on a categorical basis ${ }^{1}$. The most well-known and widely used database to measure regime type (Polity IV, in its most recent version $)^{2}$ provides a scale that ranges from negative ten $(-10)$ to positive ten $(+10)$, based on several indicators of democracy. The Polity scheme consists of six component measures that record key qualities of executive recruitment, constraints on executive authority, and political competition from 1800 to 2010. More specifically, the measure is composed of six indicators: regulation of chief executive recruitment, competitiveness of Executive recruitment, openness of Executive recruitment, Executive constraints, regulation of participation, and competitiveness of participation. Clearly, several of the indicators used to

For a comprehensive list of the composite measures of democracy see Bueno de Mesquita, Downs, Smith, and Cherif (2005; 440-441).

2 The website for the project can be found at: http://www.systemicpeace.org/polity/polity4.htm [last visited on July 14, 2012]. 
measure regime type within the Polity IV project overlap with measures of human rights protection. This presents problems of endogeneity, as one cannot disentangle the causal relationships at work. Regardless of the limitations of this database, it remains central to the research agenda that seeks to explore the impact of democracy and democratization on the level of human rights protection. This is true for all but one of the articles that I will review next, namely texts by Christian Davenport, Beth Simmons, and Todd Landman.

To that effect, Bueno de Mesquita, Downs, Smith, and Cherif (2005a) offer an attempt to unpack what might be hidden in Polity's measure of democracy, with respect to human rights protection. Their article disaggregates the indicators used in Polity IV to explore the impact of each indicator on the protection of rights to physical integrity. The analysis spans from 1976 to 2001. Surprisingly, multiparty competition (competitiveness of participation) appeared as the key to improvement in rights protection. In other words, when moves toward democracy begin to reach a level where parties compete with each other for positions in power, one observes a clear improvement in the protection of rights to physical integrity - but not before! This is as important a finding as it is worrisome. It is important to understand that not all indicators that "together" signal shifts in regime type impact the quality of human rights protection equally. Nevertheless, from a policy standpoint, the fact that only after multiparty competition is established do we observe significant improvements in the protection of rights to physical integrity is problematic, because party competition is usually the last stage of the process of democratization and the one that can take the longest to attain. In other words, this finding is bad news when it comes to the aftermath of democratization processes with respect to human rights protection ${ }^{3}$.

The findings in this article echoed earlier research that sought to disentangle the impact of democracy and democratization - separately - on human rights protection. In fact, Davenport (2004) emphasizes the contribution of decades of empirical research to establish that democracy does indeed lead to lower levels of repression. According to this literature, democratic institutions (1) eliminate the desire for repression, (2) the need for repression, and (3) the capacity to repress (Davenport 2004; 539). But what happens during the democratization process? Davenport proposes that democracy has two distinct effects: the pacifying effect and the "taming" effect. The former has been well studied in the literature and is supported by his research, with new nuances; the latter is also present in his overview of 137 countries from 1976 to 1996. The finding regarding the "taming" effect of democracy and democratization indicates that states lower repression while

3 Bueno de Mesquita and Smith (2010) argue that the structure of government finance, understood as a leader's ability to mobilize foreign aid and natural resource rents, influences the level of repression. Leaders who are better endowed with respect for these two sources of economic leverage will limit the provision of public goods associated with democracy, such as freedom of assembly, transparency, and freedom of the press. 
continuing to restrict political behavior, often through restrictions of civil liberties, such as freedom of expression, freedom of press, and the right of assembly. Finally, Davenport identifies an unintended adverse impact of democratization on the level of human rights protection. More specifically, the process of democratization - as measured by the level of constraints imposed on the Executive - appears to be correlated with more repression. This finding is corroborated in the article by Bueno de Mesquita et al mentioned above. In fact, restrictions on the Executive and elections, for that matter, are not sufficient to attain improvements in the protection of rights to physical integrity, as multiparty competition has to be in place before one can observe significant improvements in these rights.

Democracy, thus, remains a key variable in the study of human rights protection, from the international political economy perspective. An earlier work by Andrew Moravcsik has explored the rationale for behavior amongst three categories of countries, grouped according to their regime type: established democracies, new democracies, and unstable or non-democracies (Moravcsik 2000). The article analyses the preferences of these three categories of states during the negotiation that led to the creation of the European Court of Human Rights in 1953. Common wisdom, rooted in our pre-conceived ideas about democratic regimes, would expect established democracies to support a strong court, which Moravcsik characterizes as a regime that contemplates compulsory jurisdiction and the right to individual petition. Surprisingly, during this four-year negotiation, support for a strong regime came from the new democracies: Austria, France, Italy, Iceland, Ireland, and Germany (continuous democracy since a date between 1920 and 1950, as opposed to established democracies: continuous democracy since a date before 1920). Moravcsik does not find much room to account for this paradox within the traditional international relations scholarship; he proceeds to offer a new theoretical paradigm, within which behavior by the new democracies could be explained as an attempt to "lock in" the gains from democratization and to protect this asset from future attempts against the regime. Because established democracies are less prone to such risks, they are not ready to incur the costs of delegation associated with a strong international human rights regime. Moravcsik's work has important implications for research on international human rights regimes, as other scholars have departed from similar assumptions to account for state behavior with respect to the signing and ratification of international human rights treaties, on one hand, and the impact of these actions on the level of protection, on the other.

In a similar vein, Beth Simmons' 2009 book, Mobilizing for Human Rights, offers an unmatched effort for comprehensively assessing the motivations of states to sign and ratify the six core treaties that form the international human rights regime. The book sets off to ask whether signing and ratifying these treaties has any influence on state behavior regarding the protection of the rights contemplated thereto, and if so, how this influence 
can be understood within a theoretical framework. Her analysis deals with the well-established link between economic development and higher levels of human rights protection - a subject I will come back to in the next section - and takes a new approach by incorporating domestic constraints into the model. It also accounts for states' cultural and religious backgrounds. She identifies three patterns of behavior amongst the countries in her project: those that ratify and comply with treaty requirements, those that ratify and do not comply (false positives), and those that do not ratify but comply nevertheless (false negatives). She is mostly interested in explaining behavior by these two latter groups. In particular, a better understanding of the motivations of "false positives" could help scholars and practitioners involved with policy design and implementation. For Simmons, ratification of human rights agreements is a rational decision, whereby states think about expectations regarding the net costs associated with joining the regime, given a set of preferences and state practice. Ratification is therefore "rationally expressive," because the decision to join a regime sends a message to the international community as well as to peers in the region. Regional effects and emulation are a big factor in her explanation for false positives behavior. As the number of ratifications of a human rights treaty increases in a region, outsiders are compelled to join, even though they have no intention of complying. This explains why the most repressive regimes have actually signed and ratified the International Covenant on Civil and Political Rights and the Convention against Torture.

Simmons' contribution is particularly innovative and important when it comes to the analysis of the domestic constraints associated with the ratification and implementation processes. She treats them as legal integration costs, and they come in two sorts: ex ante and ex post legal integration costs. Ex ante costs refer to the relationship between the Executive and the Legislative within ratifying countries, and to the legal regime in place (civil law v. common law). Ex post costs refer to uncertainty and adjustment costs, and to costs of irreversibility. The higher the legal integration costs, the more skeptical a state will be toward ratification and compliance. She proceeds to test several hypotheses empirically in order to assess the impact these costs would have on the rate of ratification, on the use of reservations and on the decision to join additional protocols that strengthen treaty commitments through the delegation of adjudicative powers. Very generally, her results indicate that states with a British legal heritage, or those where a version of common law dominates, ratify at a lower rate and are more skeptical towards delegating powers through additional protocols. They also submit more reservations. Regarding the cultural and religious background, another strong finding is consistent across models: Catholics ratify at a higher rate, submit fewer reservations and are more likely to join additional protocols, delegating adjudicative powers and allowing individuals to petition directly to 
treaty bodies. These results are followed by a finding of strong regional effects that corroborate the "emulation" argument she proposes.

To conclude this overview of the recent literature, within the field of international political economy, that analyzes the impact of democracy and democratization on the level of human rights protection I discuss the book by Todd Landman, who, together with Beth Simmons, followed the investigation launched by Oona Hathaway in her 2002 article. All three scholars have consistently found that democracies ratify human rights treaties at a higher rate than non-democracies. But whether ratification has any observable impact on the level of protection is not a consensual issue. Hathaway found no significant relationship between ratification and improvements in the level of protection. A few years later, and using an extended version of the same dataset, Landman arrived at a more optimistic finding: ratification - or the very existence of an international human rights regime, is starting to have an impact on state behavior (Landman 2005). Based on his analysis, he suggests that democracies ratify at a higher rate and protect at higher levels. Amongst democracies, those that belong to the fourth generation (1990-1994) ratify more and with fewer reservations, but protect less.

The work discussed in this section focuses on the role of democracy and democratization in the level of human rights protection, addressing first generation rights. The authors unveiled important relationships, and in all cases they controlled for intervening factors, which has become standard practice in the field. A non-exhaustive list of the several control variables that they incorporate in their models includes: the occurrence of conflict, internal and international, population size, trade and economic development. In the next section I will focus on the scholarship that has treated development as an independent variable, looking for causal relationships between development and the level of rights protection. For this literature, in turn, regime type will be mostly treated as a control variable.

\section{Economic Development}

Research on the relationship between development and the protection of human rights can be organized in at least two groups: first, articles that address the consequences of economic development for rights protection too simply, second, articles that focus on specific instruments of economic development, such as foreign investment, preferential trade agreements, World Bank and International Monetary Fund programs, international aid - and their impact on the protection of human rights. In both cases, the literature is dealing with first generation human rights, and, for the most part, rights to physical integrity. I will follow this structure and present research that has shifted the way scholars have traditionally looked at political structures, development and well-being, followed by 
three articles that analyze the impact of specific instruments of development on rights protection $^{4}$.

The 2003 book by Bueno de Mesquita, Smith, Morrow and Siverson, The Logic of Political Survival, offers a fresh perspective on international relations theory and its contribution to understanding phenomena in real world politics. The book introduces an innovative way to look at political structures and the way politicians mold these structures to pursue their own self-interest. It departs from the assumption that every leader wants to remain in power and that therefore political survival is their first and foremost preference. The decisions leaders make in a polity are oriented towards securing his or her political survival, and the decision to protect the rights of individuals under their jurisdiction is no exception. To that end, human rights protection falls under the category of public goods, strictu sensu, in that protection of those rights meets the criteria on non-excludability and non-rival consumption. In simple terms, once these goods are made available anyone in the polity can enjoy their benefits; moreover, consumption (or enjoyment) by one group does not diminish the supply of the good for other groups.

With these preliminaries in mind, every polity consists of a group of residents, some of whom have the capacity to take part in deciding who the leader will be. Individuals who can participate in the selection of the leader belong in a group called the selectorate. Similarly, in every polity there is a leader (or leadership) and a challenger who wants to replace the leader. In order to remain in power, the leader needs the support of a winning coalition or the group of individuals drawn from the selectorate, whose support is essential if the leader is to stay in power. The winning coalition can be very small - as in most authoritarian regimes - or quite large, like electing majorities in a democracy. According to the model, leaders dealing with a small winning coalition will choose to reward these individuals with private goods in exchange for their support. Private goods are adequate here because the group of beneficiaries is small, otherwise it would become prohibitively expensive to do so. In large winning coalition regimes, as most democracies are, because leaders cannot compensate their loyal supporters with private goods they turn to the provision of public goods instead. Human rights protection is one amongst various forms of compensation that fall under the public good category. It is easy to understand how the authors account for the fact that the level of human rights protection is higher amongst democracies - precisely the regimes that are characterized by large winning coalitions.

Another applicable contribution, drawing directly from their research, relates to the dynamic aspect of their model, especially regarding economic development. They show

4 For an overview of the traditional explanations of economic development - or wealth, and the protection of human rights, see Poe, Tate, and Camp Keith (1999) and Milner, Leblang, and Poe (2004). 
how large winning coalition regimes are generally correlated with higher GDP per capita and growth rates, while small winning coalition regimes tend to be poorer, on average (Bueno de Mesquita et al 2001). As the size of the winning coalition grows, for example, during transitions to democracy, growth rates shrink and GDP per capita goes down even below pre-existing small winning coalition levels! This finding indicates that the "road to democracy" is problematic and can sidestep into authoritarian recesses quite easily. This result goes hand in hand with the analysis of the consequences of democratization for the protection of human rights offered in the previous section. Nevertheless, once a polity reaches a certain threshold, growth resumes and GDP per capita reflects the new scenario.

Results from this research agenda bring insightful warnings to scholars and policymakers working with human rights protection in transitional societies. Commitments to higher levels of protection may be - and often are - self-serving to the leadership, who will have to combat declining economic performance as a consequence of the shift from an emphasis on the provision of private goods to the provision of public goods, human rights included.

A nuanced discussion within the same general framework is offered by Bueno de Mesquita and Downs (2005b). As the title of the article, Development and Democra$c y$, suggests, the authors seek to investigate whether the common wisdom that economic development inevitably leads to democratization holds true. They begin by looking at examples that defy widely held beliefs regarding the link between development and democracy: Russia and China are the culprits. In these two cases, one sees steady economic growth unmatched by significant improvements along the democratic scale - with well documented implications for human rights protection. They proceed to argue that leaders have become increasingly savvy when it comes to managing growth spurts and spillovers to prevent the empowerment and mobilization of the middle classes, which, according the traditional story, would bring about democratization and accountability. Leaders do so by differentiating between coordination goods and traditional public goods. The former are essential to development, while the latter are key to enabling empowerment and mobilization - ultimately bringing about democratization. To be clearer, coordination goods involve things like accessible higher education, political rights, freedom of press and human rights, more broadly. Traditional public goods, in their analysis, consist of things like infrastructure, public health, primary education, transportation, and security. These are essential for economic activity to take root and bloom. Curtailing the provision of these goods would adversely impact economic growth itself. So leaders choose the best of both worlds: growth, which compensates their winning coalitions, in the traditional non-rival consumption pattern, with the political status quo that results from a deliberate effort to 
halt political mobilization through the withholding of coordination goods. Other examples include Cuba and Venezuela. An empirical study of 150 countries, between 1976 and 1999 found that economic growth accompanied by effective restriction of coordination goods delays democratization by 5-10 years (Bueno de Mesquita and Downs 2005b).

Leaders' concerns with their political survival is the key concept in this research agenda. The model challenges the old-fashioned view of democracy as a heuristic asset, to demonstrate that leaders governing a democratic country are no less self-interested than those heading an authoritarian regime. Strategies for political survival will vary in each case, with important consequences for human rights protection. But the attentive scholar and practitioner may want to keep an eye on his or her policy goals, discounting the rhetoric that is often present in democratic discourse. Skepticism is also the word of order in the three articles that I discuss next, which deal with economic tools and their effectiveness in attaining improvements in rights protection.

The first article, by Emily Hafner-Burton, investigates whether preferential trade agreements that address human rights have an impact on the level of rights protection in the target country (Hafner-Burton 2005). She discusses two mechanisms of influence that are well researched in the literature: persuasion and coercion. Persuasion is widely studied and advocated amongst constructivist international relations scholars, for whom the preferences of states are constantly being shaped by other states involved in the process. In other words, preferences and choices of action are socially influenced. Persuasion is a prominent mechanism to reach conformity with norms and rules. Conversely, the second mechanism discussed in the article, coercion, draws from a rationalist approach to state behavior, closer to the realist and institutionalist international relations scholarship. Coercion presupposes the capability to impose a credible threat and the means to implement it. It also requires that the threat represent a meaningful loss for the target country. Hafner-Burton's research design offers ample opportunity to observe the two mechanisms at work, as her dataset of preferential trade agreements negotiated by the European Union and the United States with various countries contemplates both mechanisms. Indeed, some agreements include a soft clause whereby states that are entering the agreement commit to improving the situation of human rights in their territory. In these soft agreements, there is no penalty for failing to comply. The other set of agreements, so-called hard agreements, include the same human rights clause, but condition the continuation of the agreement to real improvements in the level of rights protection. In other words, if the target country does not improve the situation of human rights in its territory, it will lose the trade benefits associated with the agreement.

After exploring the argument in favor of coercion and discussing several cases, she proceeds to the empirical part of the analysis, which covers 176 countries from 1976 to 
2001 and is circumscribed to physical integrity rights. She finds no evidence that preferential trade agreements that include a soft human rights clause have an impact on the level of rights protection. Agreements that include a hard clause raise the probability that a country will provide better protection. Her findings offer valuable insights into the operating mechanisms of any tool that embeds a threat, such as economic sanctions, for example. Based on her model, one would expect economic sanctions that seek to improve the situation of human rights protection in the target country to operate in much the same way.

Subsidies from Hafner-Burton's article on preferential trade agreements fed another - more ambitious - book project, where she deepens the analysis to the case-study level in order to explore the role of policymakers and the Executive, the Legislative, unions and non-governmental organizations in negotiating preferential trade agreements that include human rights clauses (Hafner-Burton 2009). From the outset, she articulates that the preferences of these actors are subject to the impact of institutions and to the role of power. Based on her case studies she argues that preferences within the Executive tend to prevail, despite the growing role of civil society and the dynamic of Executive-Legislative relationships in both the U.S. and the European Union. Along the way, she reveals the dominant concern from the American perspective, which is labor standards and the prohibition of child labor, whereas within the European Union the preoccupation centers around the protection of civil liberties and the electoral process. Her case studies are nicely woven to explore the theoretical propositions regarding the role of preferences, institutions and power.

In a similar vein Richards, Gelleny, and Sacko analyze the role of foreign capital with regard to human rights protection (2001). In order to capture specific forms of capital inflow, the authors created the concept of foreign economic penetration, which can take one of four forms: i. foreign direct investment; ii. portfolio investment; iii. debt (international loans by private companies); and iv. government aid. They review competing explanations and expectations regarding the role of foreign capital, with implications for hypotheses related to human rights protection ${ }^{5}$. Their empirical analysis covers 43 countries, between 1981 and 1995, and looks into the protection of rights to physical integrity as well as other political rights and civil liberties. Their results show that portfolio investment is associated with higher levels of protection of rights to physical integrity, whereas foreign direct investment seems to improve the protection of civil liberties and other political rights. Debt levels are correlated with lower levels of protection for all categories of rights covered in their analysis.

The authors acknowledge the lack of consensus in the literature regarding the consequences of foreign capital for the protection of human rights. The empirical record on the subject is at least mixed. For more on this topic see Henderson 1996, and Meyer 1996; 1998. 
This article reinforces the argument according to which economic instruments of influence that are based on coercion seem to have an impact on human rights protection. In the case of foreign direct investment and portfolio investment, the threat to withdraw the capital operates as if it was a sanction. It represents the "stick" part of the argument in the classic carrot vs. stick story. Their finding regarding the impact of debt levels deserves to be further explored and is worth a dedicated investigation.

I will now discuss an article that analyzes the impact of World Bank adjustment agreements on the protection of human rights within receiving countries (Abouharb and Cingranelli 2006) ${ }^{6}$. The authors begin by acknowledging the selection bias problem that affects their research: the World Bank quite naturally focuses its actions on countries that are poor and that have big populations. These two characteristics are well studied in human rights literature, and appear to be correlated with worse levels of human rights protection. Thus, the World Bank's actions target regimes that have traditionally been the worse violators. The authors attempt to account for the selection bias through several statistical techniques. They proceed to formulate and test three hypotheses, using a dataset comprising 442 adjustment agreements that were implemented throughout the years. The authors find strong evidence for the first two hypotheses: the negotiation hypothesis, according to which during the negotiation of an agreement with the Bank, one should observe an improvement of rights protection; the second hypothesis - the implementation hypothesis - expects the level of protection to decrease when the implementation of the agreement takes place. The logic that informs both hypotheses is quite similar. Leaders need to impart their resolve and ability to address the human rights situation within their territory to World Bank officials. These negotiators can easily walk away from the negotiation if leaders fail to show this resolve during the negotiation, through observable better human rights practices. After the negotiation is over, during the so-called implementation phase, leaders no longer have the same incentives. Moreover, they will most likely face the impact of adjustment policies in their economies, which often generates greater demands from incumbents, dissent and, commonly, repression - hence the worse record of human rights protection following the implementation of World Bank adjustment agreements. The authors find empirical support for both hypotheses.

Aside from World Bank programs, general assistance is also dispersed through foreign aid, often bilaterally. The impact of aid on human rights is a development from recent research in Political Science that seeks to look at aid as an instrument to promote the political survival of leaders - both from the donor and the recipient countries' sides ${ }^{7}$.

$6 \quad$ For more on the impact of structural agreements on human rights protection see Pion-Berlin 1984; Franklin 1997; Camp Keith and Poe 2000.

7 Several authors have studied the impact of foreign aid from an economic perspective. Among 
Bueno de Mesquita and Smith (2009) modeled the pattern of donations amongst OECD countries between 1960 and 2001, and found that aid transfers improve the survival of political leaders in both donor and recipient countries. The same is not true for poverty alleviation. The study follows earlier work by the same authors (2007), wherein the focus was on American aid alone.

The group of articles presented in this section discusses the role of and causal mechanisms behind selected economic tools and their influence on human rights protection. The findings of this literature challenge conventional wisdom regarding the World Bank and its policies of poverty alleviation and development, with important implications for other international institutions, such as the International Monetary Fund. Overall, the literature presented here suggests that states and private actors enjoy a better human rights record when it comes to devising and implementing economic tools of influence. I refer specifically to the use of preferential trade agreements that contain hard human rights clauses by states and to foreign economic penetration by firms as well. The same is not true for foreign aid, where the literature suggests that states prioritize personalistic preferences regarding the political survival of leaders, often to the detriment of the humanitarian goal of poverty alleviation and human rights.

\section{Economic Development Questions Unanswered and Further Re- search}

Several questions remain open regarding this research agenda. This recent international political economy investigation of human rights issues has focused on well-established relationships within the connected fields of democracy, development, and trade. As a consequence, the questions that guided the investigation mirrored the nature of the inquiry formulated elsewhere, without always accounting for the peculiarities of human rights as a topic.

Examples of questions that offer good territory for future research include the nature of the transition to democracy of states that have become democratic within the timeframe of the investigation. We know very little about the pros and cons of negotiated transitions. They appear to present a lesser threat for the protection of human rights, but evidence is scattered and the theoretical explanations lacking. Related to that, processes

others, William Easterly (2002; 2006), Jeffrey Sachs (2005) and Sachs and Warner (2001). For a broader analysis of the limits of foreign aid to alleviate poverty and promote better human rights practices, see also Easterly, Levine, and Roodman (2004), and Dollar and Collier (2002). For studies on the selective use of foreign aid, see Alesina and Dollar (2000), and Dollar and Levin (2006). 
of democratization often entail the incorporation of dissident groups that used to operate outside of the political spectrum, if not in plain illegality. These groups may have resorted to terror or insurgent techniques, but, historically, we have observed cases where they became part of the political game and began to voice their political preferences within a (more) democratic discourse. In the same vein, the literature on economic sanctions has found that amongst authoritarian regimes, different categories of regimes are affected in specific ways, therefore making the success of sanctions and their impact on human rights protection somewhat contingent on regime characteristics (Escriba-Folch and Wright 2010). This literature identifies four categories of authoritarian regimes, and which among these personalist regimes are most at risk when it comes to consequences of sanctions for the political survival of leaders ${ }^{8}$. This research suggests that not all repressive regimes are alike, so perhaps short of full democratization, practitioners should look for alternative outcomes as a stepping stone toward a better record of rights protection. Finally, we need to expand our knowledge into the territory of other first generation rights. Understandably, the literature has focused on rights to physical integrity because the data available limits the scope of the investigation of other categories of rights. But as some of the research suggests, other rights and civil liberties are equally important for securing a sustainable and long term political regime that is committed to the highest levels of human rights protection.

To summarize, this article identifies four areas for further research:

i. Negotiated v. abrupt transitions

ii. Incorporation of dissident political groups

iii.Nature of the authoritarian regime

iv. Beyond rights to physical integrity

Following this trend, the literature has focused primarily on empirical studies of well-documented phenomena. More recently, normative approaches that build on some of these empirical findings have emerged. Among them, the 2013 book by Emilie Hafner-Burton, Making Human Rights a Reality, stands out. In it, the author advocates that states especially states that are well positioned to act (stewards) - should focus on strategies that work, even if these do not overlap with the more general norm of rights protection. The author highlights the role of coincidence, coercion, and persuasion as effective strategies to promote rights protection, suggesting that there is no general solution for every case, but rather, that scarce resources should be allocated in the most efficient way possible.

8 There is a growing literature on the impact of economic sanctions for the protection of human rights. Even though this topic is beyond the scope of this article, those interested in the subject can find more about the consequences - often of an adverse nature - of economic sanctions for human rights in Escriba-Folch and Wright (2010), Peksen (2009), Peksen and Drury (2009), Carneiro and Elden (2009), and Wood (2008). 


\section{Final Remarks}

This research note discussed the recent scholarship within the field of international political economy that has analyzed various factors shown to impact the level of human rights protection - focusing on rights to physical integrity. The article systematized this literature into two broad categories: research dealing with the consequences of democracy and democratization for human rights protection, and research dealing with development and related economic tools for the level of rights protection.

The findings in both categories of literature challenge conventional wisdom rooted in the benevolent consequences attributed to both democracy and development. Primarily through quantitative analyses, the authors point to several unintended adverse consequences of democracy (and democratization) as well as development for the protection of human rights.

A better understanding of the causal mechanisms behind some of these consequences may assist researchers in the quest for recommendations that can successfully mitigate - if not eliminate - these adverse outcomes. We hope to have contributed to this effort by inviting researchers to take a closer look at the issue.

Revised by Priscila Moura

Submitted in November 2012

Accepted in August 2013

\section{References}

ABOUHARB, Rodwan and CINGRANELLI, David. (2006), "The Human Rights Effects of World Bank Structural Adjustment, 1981-2000." International Studies Quarterly 50(2), pp. 233262.

ALESINA, Alberto and DOLLAR, David. (2000), "Who Gives Foreign Aid to Whom and Why?" Journal of Economic Growth 5(1), pp. 33-63.

BUENO DE MESQUITA, Bruce and SMITH, Alastair. (2007), "Foreign Aid and Policy Concessions." Journal of Conflict Resolution 51(2), pp. 251.

BUENO DE MESQUITA, Bruce and SMITH, Alastair. (2009), "A Political Economy of Aid." International Organization 63(2), pp. 309-340.

BUENO DE MESQUITA, Bruce and SMITH, Alastair. (2010), "Leader Survival, Revolutions, and the Nature of Government Finance." American Journal of Political Science 54(4), pp. 936950.

BUENO DE MESQUITA, Bruce; DOWNS, George; SMITH, Alastair; CHERIF, Feryal. (2005a), "Thinking Inside the Box: A Closer Look at Democracy and Human Rights." International Studies Quarterly 49(3), pp. 439-458. 
BUENO DE MESQUITA, Bruce and DOWNS, George. (2005b), "Development and Democracy." Foreign Affairs 84(5), pp. 77-86.

BUENO DE MESQUITA, Bruce; MORROW, James; SIVERSON, Randolph; SMITH, Alastair. (2001), "Political Competition and Economic Growth." Journal of Democracy 12(1), pp. 58-72.

BUENO DE MESQUITA, Bruce; SMITH, Alastair, SIVERSON, Randolph; MORROW, James. (2003), The Logic of Political Survival. Cambridge, MA: MIT Press.

CAMP KEITH, Linda and POE, Steven C. (2000), "The United States, the IMF, and Human Rights". In David Forsythe, Ed. The United States and Human Rights. Lincoln, NB: University of Nebraska Press.

CARNEIRO, C. Lucena and ELDEN, Dominique. (2009), "Economic Sanctions, Leadership Survival, and Human Rights." University of Pennsylvania Journal of International Law 30(3).

DAVENPORT, Christian. (2004), "The Promise of Democratic Pacification: An Empirical Assessment." International Studies Quarterly 48(3), pp. 539-560.

DOLLAR, David and COLLIER, Paul. (2002), "Aid Allocation and Poverty Reduction." European Economic Review 46(8), pp. 1475-500.

DOLLAR, David and LEVIN, Victoria. (2006), "The Increasing Selectivity of Foreign Aid, 19842003." World Development 34(12), pp. 2034-46.

EASTERLY, William. (2002), The Elusive Quest for Growth: Economists' Adventures and Misadventures in the Tropics. Cambridge, MA: MIT Press.

EASTERLY, William. (2006), The White Man's Burden: Why the West's Efforts to Aid the Rest Have Done So Much Ill and So Little Good. London: Penguin Press.

EASTERLY, William; LEVINE, Ross; ROODMAN, David. (2004), "Aid, Policies, and Growth: Comment." American Economic Review 94(3), pp. 774-80.

ESCRIBA-FOLCH, Abel and WRIGHT, Joseph. (2010), "Dealing with Tyranny: International Sanctions and the Survival of Authoritarian Rulers." International Studies Quarterly Vol. 54, pp. 335-359.

FRANKLIN, James. (1997), "IMF Conditionality, Threat Perception, and Political Repression: A Cross-National Analysis." Comparative Political Studies Vol. 30, pp. 576-606.

HAFNER-BURTON, Emilie. (2005), "Trading Human Rights: How Preferential Trade Agreements Influence Government Repression.” International Organization 59 (Summer), pp. 593-629.

HAFNER-BURTON, Emilie. (2009), Forced to Be Good: Why Trade Agreements Boost Human Rights. Ithaca, NY: Cornell University Press.

HAFNER-BURTON, Emilie. (2013), Making Human Rights a Reality. Princeton, NJ: Princeton University Press. 
HENDERSON, Conway. (1996), "Dependency and Political Repression: A Caveat on Research Expectations." D. L. Cingranelli, Ed. Human Rights and Developing Countries. Greenwich, CT: JAI Press.

LANDMAN, Todd. (2005), Protecting Human Rights: A Comparative Study, Advancing Human Rights. Washington, D.C.: Georgetown University Press.

MILNER, Wesley; LEBLANG, David; POE, Steven. (2004), "Providing Subsistence Rights: Do States Make a Difference?" Sabine Carey and Steven Poe, Eds. The Systematic Study of Human Rights. Burlington, NY: Ashgate.

MEYER, William H. (1996), "Human Rights and MNCs: Theory versus Quantitative Analysis." Human Rights Quarterly Vol. 18, pp. 368-397.

MEYER, William H. (1998), Human Rights and International Political Economy in Third World Nations. Westport, CT: Praeger.

MORAVCSIK, Andrew. (2000), "The Origins of Human Rights Regimes: Democratic Delegation in Postwar Europe." International Organization 54(2), pp. 217-252.

PEKSEN, Dursun. (2009), "Better or Worse? The Effect of Economic Sanctions on Human Rights." Journal of Peace Research 46(1), pp. 59-77.

PEKSEN, Dursun and DRURY A. C. (2009), "Economic Sanctions and Political Repression: Assessing the Impact of Coercive Diplomacy on Political Freedoms." Human Rights Review 10(3), pp. 393-411.

PION-BERLIN, David. (1984), "The Political Economy of State Repression in Argentina." Michael Stohl and George Lopez, Eds. The State as a Terrorist: The Dynamics of Governmental Violence and Repression. Westport, CT: Greenwood Press.

POE, Steven; TATE, Neal Tate; CAMP KEITH, Linda. (1999), "Repression of the Human Right to Physical Integrity Revisited: A Global Cross-National Study Covering the Years 1976-1993. International Studies Quarterly Vol. 43, pp. 291-313.

RICHARDS, David; GELLENY, Ronald; SACKO, David. (2001), "Money with a Mean Streak? Foreign Economic Penetration and Government Respect for Human Rights in Developing Countries." International Studies Quarterly 45, pp. 219-239.

SACHS, Jeffrey and WARNER, Andrew. (2001), "The Curse of Natural Resources." European Economic Review 45(4-6), pp. 827-38.

SACHS, Jeffrey. (2005), The End of Poverty: Economic Possibilities for Our Time. New York: Penguin Books.

SIMMONS, Beth. (2009), Mobilizing for Human Rights: International Law in Domestic Politics. Cambridge, MA: Cambridge University Press.

WOOD, Reed M. (2008), "A Hand upon the Throat of the Nation: Economic Sanctions and State Repression." International Studies Quarterly 52, pp. 489-513. 